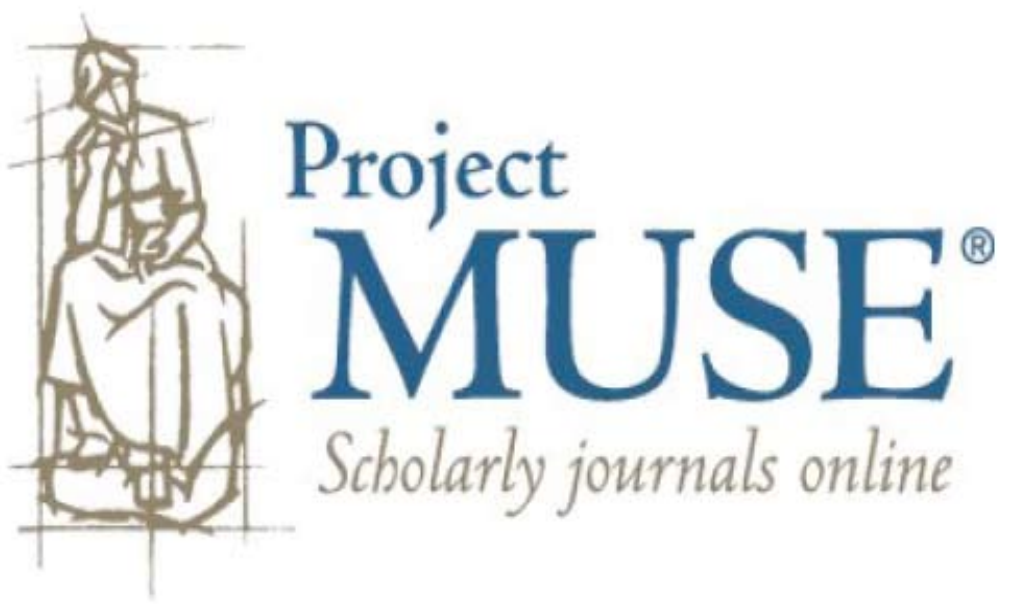




\title{
POLITICAL ENGINEERING IN THE ASIA-PACIFIC
}

\author{
Benjamin Reilly
}

Benjamin Reilly is the director of the Centre for Democratic Institutions and associate professor in the Crawford School of Economics and Government at the Australian National University. His essay "Electoral Systems for Divided Societies" appeared in the April 2002 issue of the Journal of Democracy.

$\mathrm{T}$ hroughout the 1980s and much of the 1990s, the rapid economic development of Indonesia, South Korea, Malaysia, Singapore, Taiwan, and other Asia-Pacific countries under restrictive political arrangements led to claims of the superiority of a so-called Asian model of democracy. ${ }^{1}$ Touting the strength of Asian culture and values in contrast to the perceived moral turpitude and social decay of the West in general and the United States in particular, proponents of "Asian-style democracy" argued for the virtues of quasidemocratic government that ranked hierarchy and order over individualism and competition. In truth, this was at base a model of nondemocracy - and one that faded quickly from prominence in the wake of the 1997 financial crisis, which laid bare the structural weaknesses of East Asia's political and economic systems.

The political reforms that the region has seen since then have set the stage for the advent of a more genuine "Asian model" of democracy. In something of a grand irony, this model is coming to resemble the AngloAmerican system of majoritarian electoral competition and two-party politics. This movement toward more predictable and consolidated representative government has been eased by strategies of overt political engineering across an increasingly diverse array of electoral democracies in Northeast Asia, Southeast Asia, and the Pacific islands. Regimes throughout the region have sought to recraft their political systems in order to encourage elections that are more decisive, parties that more coherently aggregate interests, and governments that are more stable.

The number of Asia-Pacific governments chosen through free and competitive elections reached an all-time high in recent years. In a 
region that just a decade ago lay largely under authoritarian sway, there is now a clear trend toward accepting democracy as the only legitimate means for choosing and changing a country's political leadership. Over the past two decades, successful transitions from authoritarian rule have taken place in East Timor, Indonesia, Korea, the Philippines, Taiwan, and Thailand (although the Thai coup of September 2006 may mark the end of this process). Liberal democracy has also survived, although not without problems, in Papua New Guinea and most of the Pacific-island countries. With the addition of Japan (East Asia's sole established democracy), this means that most of the Asia-Pacific's major states, bar China, are today competitive electoral democracies-a truly historic shift in world affairs.

The quest for more representative and effective governance across the region has spurred broad institutional reforms that focus on rewarding or constraining particular kinds of behavior. Many political-engineering strategies concentrate on the creative design of electoral systems as the institutions best suited to promoting better representation and governance. Long-running scholarly debates are gaining renewed realworld cogency as Asia's decision makers and citizens discuss the relative merits of presidentialism versus parliamentarism; the devolution of power via decentralization, federalism, or regional autonomy; the development of political parties and party systems; and the design of constitutional structures more generally. All these debates seek answers to what Giovanni Sartori, writing almost forty years ago, called "the central question of political engineering," namely, "How can we intervene politically in steering and shaping a process of political development?"2

Across the Asia-Pacific region, ambitious and often highly innovative forms of political engineering have lately become the norm. Electoral reforms in ethnically heterogeneous new democracies such as Indonesia have sought to promote crossregional political parties that can operate as agents of social integration. Japan, Korea, the Philippines, Taiwan, and precoup Thailand each introduced majority-enhancing electoral systems intended to foster political aggregation and penalize splinter parties, while a number of states-Indonesia again prominent among them-have embarked upon major exercises in political and administrative decentralization. In the island Pacific, the troubled but resilient postcolonial democracies of Papua New Guinea and Fiji (which suffered a coup in December 2006) have introduced ambitious constitutional-reform packages designed to aid stable multiethnic governance.

A number of broader trends have driven reforms across the region. For instance, many recent interventions in political development echo the way that East Asia's industrializing states used targeted sectoral strategies in the 1970 s and 1980 s to promote economic growth. Japan, South Korea, and Taiwan were the most prominent exemplars of this "developmental-state" model, which relied on interventionist indus- 
trial policies rather than the invisible hand of the market. With the democratic transitions of the 1990s, this interventionist approach to economic development began to be replicated in the political arena as well, through deliberate strategies of political engineering. Attempts to craft "democratic developmental states" in the Asia-Pacific region can thus be seen as efforts to extend into the political arena an approach that once worked in the economic sphere. Ironically, the 1997 Asian financial crisis, which dealt a severe blow to the state-guided development model, also helped this process by giving voice to long-repressed social cleavages, delegitimizing incumbent leaders, and stimulating an intense struggle for political reform in countries such as Indonesia, Thailand, and South Korea.

\section{Electoral Engineering}

A particularly striking political-engineering trend in recent years has been in the area of electoral-system design. Because electoral systems determine how votes translate into seats, such systems are central to deciding who governs. The elements that make up an electoral system-the votes-to-seats formula, the way that districts are drawn, the structure of the ballot, and the extent to which voting is candidatecentered or party-centered-each exert an independent influence on the behavioral incentives facing political actors, and hence on the development of political parties and the kinds of campaign strategies and policy appeals that parties employ.

Although forms of government, political cultures, and degrees of democratic consolidation differ from country to country, patterns of reform across the region show more evidence of convergence than divergence. Japan, South Korea, Taiwan, the Philippines, and Thailand have all enacted strikingly similar electoral reforms. One clear trend is the growing popularity of mixed electoral systems that combine aspects of proportional representation (PR) with the majority (or plurality) principle in order to gain the advantages of both. A PR system's basic aim is to give each party a share of legislative seats that matches its share of the overall vote, ensuring that even small minorities can be fairly represented. The most common type of PR calls for each voter to choose en bloc among a number of lists of candidates rather than to vote for individuals. Plurality or majority systems, by contrast, usually feature a competition between individual candidates, and typically ensure that the party winning more votes than any other (a plurality) or more than half the votes (a majority) can control the legislature.

In mixed systems, PR governs the choice of part of the legislature, usually by treating the entire country as a single at-large district, while plurality or majority rules are used to fill the rest of the seats, which are elected from discrete districts. While mixed systems have become com- 


\section{Table 1-Seats Decided by Majority/Plurality and PR in Mixed Systems}

\begin{tabular}{|l|c|c|c|}
\hline Country & $\begin{array}{c}\text { Majority/ } \\
\text { Plurality } \\
\text { SysteM } \\
\text { (District SEATs) }\end{array}$ & $\begin{array}{c}\text { Proportional- } \\
\text { RePresentation } \\
\text { System } \\
\text { (List-PR Seats) }\end{array}$ & Total Seats \\
\hline Japan & 300 & 180 & 480 \\
\hline Korea & 243 & 56 & 299 \\
\hline Philippines & 208 & up to 52* & 260 \\
\hline Taiwan & 73 & 34 & $113 \dagger$ \\
\hline Thailand & 400 & 100 & 500 \\
\hline
\end{tabular}

* no group may exceed three seats

$\dagger$ includes six additional seats reserved for aboriginal minorities

mon around the world in the past decade, they have been a particularly popular choice in Asia-perhaps because they promise to combine the sense of fairness that comes from a proportional outcome with the sense of accountability that comes from linking seats to distinct districts. ${ }^{3}$ In sharp contrast to similar reforms in other parts of the world, however, most Asian mixed systems are highly majoritarian in both design and practice, leading to quite distinctive outcomes compared to other regions.

This majoritarian bias is evident in a number of ways. As Table 1 illustrates, Asia's mixed systems, in contrast to those in Europe or Africa, are heavily weighted in favor of the district-based element of the system. In South Korea, Thailand, and the Philippines, only about 20 percent of seats are chosen by the proportional method. In Japan, the figure is 38 percent; in Taiwan's new system, it is 30 percent. In all cases, however, the bulk of seats in the legislature are chosen by plurality rules from single-member districts. The lack of any mechanism to compensate for this bias toward the plurality or majority rule, combined with the relatively small number of proportional seats on offer, penalizes smaller parties while working to the advantage of large parties with a national scope.

This distinctive political architecture stands in direct contrast to the international norm, where well-known examples of mixed systems, such as those in Germany and New Zealand, feature an equal or nearly equal split between proportional and district seats. Asia-Pacific states have also rejected the kind of compensatory mechanisms used by these countries, in which list seats are allocated in such a way as to produce proportional outcomes overall. Instead, Asia's mixed systems, like those found in much of Central Europe, run the list component of elections in parallel with the district contest, with no effort to produce any particular balance between the outcomes. Again, the effect is to advantage larger, nationally focused parties in the allocation and distribution of seats.

Despite this convergence in institutional redesign across the AsiaPacific region, the motives for introducing such systems varied from 
country to country. In Northeast Asia, the mixed system was mainly meant to ease the endemic political factionalism-bred by the single nontransferable vote (SNTV) - that had come to bedevil Japan and, in somewhat different ways, South Korea and Taiwan as well. Japanese reformers hoped that electoral reform would foster the development of a two-party system as well as political competition based on policy differences rather than squabbles over patronage. In Korea and Taiwan, where regional and national-identity cleavages are prominent, party lists now vie for votes on a nationwide basis, which encourages parties to pitch their policy messages nationally rather than tailor a number of local appeals. In Thailand, by contrast, reformers hoped that a shift to a mixed system with a majority of single-member districts would undercut the prevalence of "money politics," as local candidates would not have to rely on local agents to the same extent as they had in the past when multimember "block-vote" rules applied. In the Philippines, list seats are reserved for "sectoral interests" such as youth, labor, the urban poor, farmers, fishermen, and women, an arrangement introduced with the aim of breaking the stranglehold of the old elite families on national politics. $^{4}$

The reform trajectory in Papua New Guinea and the Pacific-island countries has been rather different: The most influential electoral reform in recent years has been the replacement of plurality systems with variants of Australia's alternative-vote (AV) system, which is based on single-member districts and requires that successful candidates gain not just a plurality but an absolute majority of votes. Under this system, voters rank-order candidates on the ballot paper in order of their choice, marking " 1 " next to their most favored candidate, " 2 " by their second choice, "3" by their third choice, and so on. Any candidate who gains an absolute majority (50 percent plus 1 ) of first-preference votes is immediately elected. If no one has a majority, the candidate with the lowest vote total is "eliminated" from the count and each ballot giving that candidate a " 1 " is rechecked for its second preference, which is then "transferred to" (that is, counted as a vote for) the appropriate candidate in a process that is repeated until one candidate has an absolute majority or until there are no votes left in the count. The two largest Pacific-island states, Fiji and Papua New Guinea, have both introduced such systems in recent years to promote majority victors and to encourage interethnic accommodation, since under such a rule it often becomes sensible for a candidate to seek the " 2 " or " 3 " votes of citizens from outside the candidate's ethnic base. ${ }^{5}$

In recent years, both mixed and (to a lesser extent) AV systems have achieved popularity around the world and not just in the Asia-Pacific region. ${ }^{6}$ Yet the Asia-Pacific's experience of electoral reform has been unusual by international standards in a number of ways. Overwhelmingly, the democracies of this region have adopted electoral systems 
whose designs and outcomes are highly majoritarian, both structurally and in practice. Strengthening political parties, reducing political fragmentation, countering SNTV-driven factionalism, and bolstering the interests of large national parties over smaller or localized ones were overt aims in almost all cases. Not coincidentally, such reforms also tend to support the interests of political incumbents by enhancing regime stability and raising the bar for new entrants to the political system. Aurel Croissant, writing about the process of electoral reform in Korea, noted that the "debate on electoral reforms focuses very much on the question of how to improve the majority generating function of the electoral system-i.e. its capability to produce single party majorities in parliament." This statement could well be applied across the AsiaPacific as a whole.

Throughout the region, reformers have also focused on encouraging cohesive political parties while limiting ethnic or minority movements. Both majoritarian-leaning mixed models (in Asia) and AV systems (in the Pacific) tend to favor large, broad-based parties that compete for the middle ground. These reform trends become even clearer after examining the many and varied attempts made by Asian and Pacific governments to shape party-system development. In addition to using the design of electoral systems to try to change the way that political parties function, many Asian and Pacific states have also attempted to reform their party systems by directly engineering the rules that govern how parties are formed, organized, and behave.

\section{Party Engineering}

Despite being indispensable to all functioning modern democracies, parties have traditionally been seen as a social phenomenon beyond the scope of deliberate engineering. In recent years, however, political reformers in a number of Asia-Pacific states have sought to influence party-system development by strengthening internal party organizations, promoting crossregional branch structures, and countering the rise of ethnic or regional parties. While such experiments have not yet come under much scrutiny, they are likely to have important consequences for governance in the region.

Scholars of democracy have long believed that political parties play a crucial role not just in representing interests, aggregating preferences, and forming governments, but also in managing conflict and promoting political stability. The extent to which parties perform these functions varies significantly, however, depending on the nature of the party system. In systems comprising two large parties, for instance, cultivating and maintaining support across a range of social groups is required to win elections, and parties therefore have incentives to provide broad public goods in order to maximize their chances of success. In frag- 
mented multiparty systems, by contrast, parties may need only a small share of the vote to win office, and can thus focus on providing sectoral benefits to their own supporters rather than appealing to the broader electorate. At an extreme, such private goods can include the fruits of nepotism, cronyism, and corruption-all problems of long standing in Indonesia,

In fragmented multiparty systems, parties may need only a small share of the vote to win office, and can thus focus on providing sectoral benefits to their own supporters rather than appealing to the broader electorate. the Philippines, Thailand, and a number of other Asia-Pacific states.

If we know that aggregative parties and party systems are desirable, the next question is how they can be nurtured. Forging cohesive party systems, particularly in societies riven by deep communal cleavages, is easier said than done. Nonetheless, recent reforms in states such as Indonesia, the Philippines, and Thailand have attempted to strengthen parties and remodel party systems through a variety of institutional incentives and constraints. Three distinct strategies of "party engineering" have emerged. First, there are those that seek to promote the development of national party systems and hamper the growth of regional, local, or secessionist parties. Then there are those that attempt to control, influence, or restrict the number of parties. Finally come those that try to strengthen party organizations by building stable party structures from the top down.

The most direct means of fostering broad-based parties that offer policies to the whole nation is to ensure that parties themselves are elected on a national basis and need support from different regions of the country and segments of the electorate. An increasing number of Asia-Pacific states now require parties to take account of regional, ethnic, and religious balance when putting forward candidates for election. Thailand, for example, requires registered parties to establish membership and branch networks in each of the country's four main regions, while for the ostensibly nonpartisan Senate elections all regions must be "equitably represented" on each candidate list. The Philippines requires parties to meet similar region-transcending thresholds: By law, each party must have an office in at least nine of the country's sixteen regions, and must gain support in more than half the cities and provinces where their candidates run. ${ }^{8}$

Indonesia has taken the engineering of party systems the farthest. While only three officially sanctioned and controlled "national" parties were allowed under General Suharto's so-called New Order regime (which was in power from the mid-1960s to May 1998), more than a hundred new parties (many with miniscule support bases) formed in just 
a few months after Suharto left office. This mushrooming of new parties provoked widespread worry that political fragmentation and democratic dysfunction might be in the offing. ${ }^{9}$ At the same time, there were overriding concerns-particularly with the breakaway of East Timor in 1999 - of secessionism in provinces such as Aceh and Papua, and the very real fear that the vast island country could splinter under separatist pressures.

Indonesia's political reformers therefore placed a complex bundle of incentives and restraints upon party-system development. As a precondition for competing in 1999's transitional elections, all parties had to demonstrate a national support base by establishing branches in onethird of Indonesia's then-27 provinces, as well as offices in more than half the districts or municipalities within each province where a party branch was claimed to exist. As Dwight King notes, "where previously the number of election contestants was stipulated by law, permitting only three, now they were limited on the basis of insufficient geographical coverage and depth of penetration of their organizations." 10 The 2004 election laws went even further: New parties had to establish branches in two-thirds of all provinces and municipalities within those provinces, while small parties that had failed in 1999 to gain more than 2 percent of the seats in parliament's lower house or 3 percent of seats in the regional assemblies found themselves forced to merge with other parties in order to qualify for the 2004 elections.

Similar but less draconian reforms have been introduced in Thailand, which has a long history of fragmented party politics leading to ineffectual coalition governments and frequent military coups-the most recent in September 2006, which will likely lead to a further round of reforms. Currently, in addition to the crossregional membership requirements noted above, new parties must show that they have at least five thousand members within six months of being registered. Thai authorities have actively enforced these new laws, disallowing parties that fail to meet them. In South Korea, local party organizations must prove that they have a minimum number of party members in a specified number of districts across the country, a requirement that "favors big parties above minor parties [and] also contributes to political stability by preventing extreme pluralism (that is, very small parties with limited public support) from emerging." even though they are aimed at restricting political fragmentation generally, rather than separatist parties in particular.

A third approach has been to try to strengthen internal party organizations by privileging party interests within the structure of government or by changing the way that candidates are nominated. In both Indonesia and Thailand, for example, all lower-house candidates must represent a political party - no independents may run. In Indonesia, new laws governing party registration stress the systemic and educational role of 
parties, whose leaders have received significant powers over candidate selection and replacement. A number of states, including less-developed countries such as Indonesia and Papua New Guinea, now also make public funds available to qualifying parties.

Changes to parties' internal-governance arrangements have also been popular. In 2001, Japan's ruling Liberal Democratic Party adopted a new selection process for choosing its president that resembled U.S.style primaries, in a move designed to amplify the voices of ordinary dues-paying members. ${ }^{12}$ The same year, the main South Korean parties unveiled similar reforms, introducing primary elections for the party leadership in a bid to revitalize membership. These reforms had an immediate impact, enabling Roh Moo-hyun, a relative outsider, to win the presidential nomination of the Millennium Democratic Party (MDP). Roh's rapid rise in popularity-particularly among younger votersand his election to the presidency in 2002 added great luster to the new "people's primary" and internal party-governance measures. Roh's rise also spurred the MDP's rival, the Grand National Party, to announce similar reforms. It remains to be seen whether these changes will be sufficient to transform Korea's weak, regionalized, and personality-dominated party system into one based on true mass parties with a national reach. ${ }^{13}$

A final means of engineering party stability is to encourage party cohesion within parliament. One way of doing this is to restrict the capacity of legislators to change parties once elected. "Party-hopping" or "turncoatism" - often induced by offers of ministerial posts or other rewards, and once widespread in many Asia-Pacific countries-has been curtailed by the introduction of "antihopping" provisions in countries such as Fiji, Malaysia, Papua New Guinea, and Thailand. In Thailand, for example, the 1997 constitution mandated that candidates must be members of a political party for at least 90 days prior to an election (the standard interval between the end of a parliamentary term and the fresh balloting is 45 days). As a result, politicians who switched parties to help bring down a government usually could not legally run in any subsequent election. ${ }^{14}$

These kinds of restrictions, however, have little sway over party defections that take place outside the parliamentary arena or in periods between elections. They also do little to combat the related problem of multiple endorsements, where the same candidate may be nominated by several parties, or where parties nominate multiple candidates for a single-seat district-a common occurrence in the Philippines, Papua New Guinea, and some Pacific-island states, where parties are weak and often irrelevant. In Papua New Guinea, for example, many electors vote for their local clan candidate rather than for political parties, meaning that independents with no party affiliation have been a major force in parliament. This has bred a degree of volatility that makes coherent 
governance difficult as parliamentary majorities shift from issue to issue and vote to vote.

In response, the Papua New Guinea government in 2001 introduced an ambitious reform package aimed at stabilizing executive government and building a coherent party system from the top down. Under the new rules, before parties can be registered to run in elections, they must allow internal competition for leadership spots and demonstrate both a written constitution and a dues-paying membership. The provision for party registration is tied to a new system of party funding under which each registered party receives the equivalent of about US $\$ 3,000$ per legislator every year (the country's 2005 GNP per capita was $\$ 2,600$ per year). The intent is to move parties away from being purely vehicles for personal advancement, and to encourage prospective candidates to run with parties rather than as independents. In addition, party-endorsed members must now vote in accord with their party's platform on key parliamentary decisions, such as a vote of confidence in the prime minister, or face a possible by-election. As every government elected prior to 2002 fell prematurely due to party-hopping, these reforms constitute one of the most far-reaching attempts to engineer a party system anywhere in the Asia-Pacific region.

\section{Has Reform Worked?}

In virtually all the Asian and Pacific-island democracies, one of reform's basic goals has been greater "political stability." This can mean several things. First, political stability sometimes refers to the maintenance of formal democracy or the avoidance of civil strife. ${ }^{15}$ A more precise definition of political stability relates to the tenure and composition of executive governments. ${ }^{16}$ Under this interpretation, political and policy continuity depends significantly on the durability of cabinets. Thus politics is more "stable" when governing executives are durable in terms of both longevity and personnel; conversely, executives are "unstable" if their composition alters frequently, particularly if governments change between elections due to no-confidence votes, impeachments, party-hopping, or similar events.

One way to assess the impact of the electoral and party-system reforms discussed above is therefore to examine the average duration of governments in the period before and after political reforms were enacted. In at least four states-Indonesia, Thailand, Papua New Guinea, and the Philippines-advocates of changes to party laws and electoral systems often pointed to the need for greater political stability. In each of these cases, the longevity of executive governments has indeed improved since political reforms were introduced.

The most striking improvement occurred in precoup Thailand, which in the wake of the 1997 reforms went from an average government 


\section{Table 2-Changes in the Effective Numbers of Political Parties}

\begin{tabular}{|c|c|c|}
\hline Country & $\begin{array}{c}\text { Effective Number of } \\
\text { Political Parties } \\
\text { (PRevious elections) }\end{array}$ & $\begin{array}{l}\text { Effective Number of } \\
\text { Political Parties } \\
\text { (Most Recent } \\
\text { Elections) }\end{array}$ \\
\hline Fiji & $3.06(1997-2001)$ & $2.22(2006)$ \\
\hline Indonesia & 4.87 (1999) & $8.30(2004)$ \\
\hline Japan & $3.30(1949-2000)$ & $2.40(2005)$ \\
\hline Korea & $2.95(1988-2000)$ & $2.36(2004)$ \\
\hline Taiwan & $2.69(1992-2001)$ & $2.18(2004)$ \\
\hline Thailand & $5.03(1992-2001)$ & $1.65(2005)^{*}$ \\
\hline Philippines & $4.90(1986-2001)$ & $3.48(2004)$ \\
\hline Papua New Guinea & $8.14(1975-2002)$ & $7.16(2005) \dagger$ \\
\hline
\end{tabular}

* Thailand's most recent elections were held in April 2006 (five months before the coup), but were boycotted by the opposition parties and subsequently annulled by the Constitutional Court. This figure refers to the February 2005 elections.

$\dagger$ Papua New Guinea's current parliament was elected in 2002, but with six seats left vacant due to the failure of the election in one province. A series of by-elections have since filled these and other vacant seats. This is the party composition of parliament as of 2005 .

Source: Aurel Croissant, "Electoral Politics in Southeast and East Asia: A Comparative Perspective," in Aurel Croissant, Gabriele Bruns, and Marei John, eds., Electoral Politics in Southeast and East Asia (Singapore: Friedrich Ebert Stiftung, 2002), 329. Author's calculations for the most recent election outcomes and for all elections for Papua New Guinea and precoup Fiji, are based on the "effective number of parties" (see note 17).

lifespan of just ten months to more than four years in the period to the end of 2005. In the Philippines, the longevity of cabinets elected under the 1987 constitution has also improved compared to the democratic period before Ferdinand Marcos came to power in 1965, although "people-power" revolutions have overthrown one elected president (Joseph Estrada) and may yet claim others. In Indonesia, the longevity of each post-Suharto president has increased incrementally. While Suharto's replacement, B.J. Habibie, lasted just seventeen months in office, he initiated fundamental political reforms, including new electoral and decentralization laws that greatly benefited his immediate successors, Abdurrahman Wahid and Megawati Sukarnoputri, whose administrations lasted for 21 and 38 months respectively. In 2004, Indonesia introduced direct presidential balloting. The winner, retired general Susilo Bambang Yudhoyono, looks set to become the first elected president to govern for a full term. Similarly, the 2001 reforms that Papua New Guinea made to promote more-secure executive tenures have led to a marked increase in political stability. In June 2006, current prime minister Michael Somare will become the first leader since independence to serve a full term instead of being overthrown from the floor of parliament. In each of these cases, reform appears to have enhanced stability, at least as measured by the limited indicator of cabinet durability.

Attempts to engineer more broadly based party systems have also met with modest success, though not always in the way intended. Most 
Asia-Pacific democracies have seen party fragmentation drop sharply in recent years. Indonesia, for example, initially experienced a mushrooming of more than a hundred new parties in the run-up to the 1999 elections. Only six achieved any significant representation, however, and the Indonesian political system quickly became dominated by a few large parties. Thus, although Indonesia's parliament remains politically fragmented, and in fact experienced a rise in the "effective number of parties" 17 between 1999 and 2004, a more coherent party system with broad support across the country does appear to be emerging.

A similar pattern appears to be at work in many other countries as well. As Table 2 illustrates, based on the effective number of political parties in parliament, party systems in Fiji, Japan, South Korea, Papua New Guinea, the Philippines, Taiwan, and Thailand have all become less fragmented lately. In countries such as Japan, South Korea, and Taiwan, embryonic two-party systems even seem to be emerging. At least part of this change can be attributed to the wide-ranging engineering of electoral and party systems in these states. As such, the wave of political reform that has swept the region over the past decade reflects not the vague concepts of "Asian values" or "Asian-style democracy," but rather pragmatic efforts to build functioning democratic systems that can spur development and have a realistic chance to endure.

\section{Two Steps Forward, One Step Back}

Party engineering entails costs as well as benefits. Indonesia's new electoral laws, for instance, benefit incumbent parties by restricting political competition and erecting barriers to potential new entrants into the political marketplace. As a result, a danger of overkill inheres in the new party provisions, especially as there are plans to heighten the barriers facing smaller parties and new entrants. Under existing legislation, most parties elected in the 2004 elections will be barred from competing in the next elections in 2009 because they failed to win more than 3 percent of the seats in 2004. These parties will be encouraged to amalgamate with others in order to reach this support marker. Even more severe restrictions will be placed on future candidates for the presidency: Under current plans for the 2009 parliamentary elections, only parties that win at least 20 percent of all votes cast, or at least 15 percent of the seats, will be entitled to run candidates for president and vice-president. All this not only discriminates against smaller parties, but tilts the electoral playing field markedly in favor of incumbents and established parties.

The overkill issue applies even more strongly to Thailand, where the 1997 constitution contained so many incentives favoring strong parties that it may have unbalanced Thai democracy. In particular, the electoral and party reforms facilitated the rapid emergence of Prime Minister 
Thaksin Shinawatra (one of Thailand's richest men) and his Thai Rak Thai (TRT) party as Thailand's dominant political players. Already in a commanding position following the 2001 elections, Thaksin initiated a series of postelection mergers and coalition deals with other parties that led to TRT dominating parliament and winning the 2005 elections by a massive margin. Following a damaging public row over his family's sale of telecommunications shares, however, Thaksin miscalculated by calling snap elections in April 2006 that were boycotted by the opposition parties. Although the TRT won, the results of these elections were subsequently annulled by the Constitutional Court. In September 2006, while Thaksin was visiting the United Nations in New York, the Thai military conducted a bloodless coup that removed him from office and abrogated the 1997 constitution. While new elections have been promised for 2007, it remains to be seen whether genuine democracy will be restored, especially given the apparently widespread popular support for the coup.

Elsewhere, the impacts of political engineering seem to be more positive. For instance, while the longer-term effects of Papua New Guinea's revised political arrangements will not be evident until the next elections are held in 2007, political consolidation does appear to have improved on a number of measures. Party fragmentation has fallen sharply, from 42 registered parties in 2001 to 15 in 2004, as has the number of candidates standing as independents. The experience of the new electoral system has also been encouraging: Six by-elections held in 2004 under the "limited-preferential" AV system all saw a sharp increase in the winning margins of successful candidates, each of whom gained an absolute majority of the vote, and a reduction in electoral violence compared to earlier elections. In ethnically divided Fiji, despite dire predictions to the contrary, the April 2006 elections also went smoothly. Attempts to engineer cooperation across communal lines received a boost when the victorious Fijian United Party formed the country's first multiethnic power-sharing cabinet with the predominantly Indo-Fijian opposition. ${ }^{18}$

How are we to interpret the broader implications of this "two steps forward, one step back" approach to political change in the Asia-Pacific region? It could be that the region's turn toward majoritarian politics signals a drift away from democratic values toward a new form of illiberal democracy-in effect, a return to Asia's long experience with dictatorial, autocratic, monarchic, or other forms of illiberal rule. But there are reasons to be optimistic. If the Asia-Pacific's emerging democracies can make the transition from fragmented, personalized, and unstable political systems to cohesive, programmatic, and stable onesas at least some appear to be doing - their prospects for both democracy and development will be significantly enhanced, as will their ability to manage internal conflicts. While political engineering cannot guaran- 
tee the achievement of these goals, it appears to be one means of smoothing and straightening the path. ${ }^{19}$

\section{NOTES}

1. There is a voluminous literature, much of it self-serving, on the subject of the "Asian model" of democracy. Important early writings include Tommy Kho, "The 10 Values Which Undergird East Asian Strength and Success," International Herald Tribune, 11-12 December 1993, 10; Fareed Zakaria, "Culture Is Destiny: A Conversation with Lee Kwan Yew," Foreign Affairs 73 (March-April 1994): 10926; Kishore Mahbubani, "The Pacific Way," Foreign Affairs 74 (January-February 1995): 100-11. For critiques from the region, see Kim Dae-Jung, "Is Culture Destiny? The Myth of Asia's Anti-Democratic Values," Foreign Affairs 73 (MarchApril 1994): 198-94; Aung San Suu Kyi, "Freedom, Development, and Human Worth," Journal of Democracy 6 (April 1995): 11-19; and Yung-Myung Kim, “"Asian-Style Democracy': A Critique from East Asia," Asian Survey 37 (December 1997): 119-34. For an overview, see Mark R. Thompson, "Whatever Happened to 'Asian Values'?" Journal of Democracy 12 (October 2001): 154-65. Also see Daniel A. Bell, East Meets West: Human Rights and Democracy in East Asia (Princeton, N.J.: Princeton University Press, 2000), 201-13.

2. Giovanni Sartori, "Political Development and Political Engineering," Public Policy 17 (1968): 272.

3. For more on mixed systems, see Andrew Reynolds, Ben Reilly, and Andrew Ellis, Electoral System Design: The New International IDEA Handbook (Stockholm: International Institute for Democracy and Electoral Assistance, 2005). For excellent recent surveys of Asian electoral systems, see Aurel Croissant, Gabriele Bruns, and Marei John, eds., Electoral Politics in Southeast and East Asia (Singapore: Friedrich Ebert Stiftung, 2002); and Allen Hicken and Yuko Kasuya, "A Guide to the Constitutional Structures and Electoral Systems of East, South and Southeast Asia," Electoral Studies 22 (March 2003): 121-51. The most comprehensive collection on the subject is Dieter Nohlen, Florian Grotz, and Christof Hartmann, eds., Elections in Asia and the Pacific: A Data Handbook, 2 vols. (Oxford: Oxford University Press, 2001).

4. For more on Japan and Taiwan, see Jih-wen Lin, "The Politics of Reform in Japan and Taiwan," Journal of Democracy 17 (April 2006): 118-31. For South Korea, see Aurel Croissant, "Electoral Politics in South Korea," in Croissant, Bruns, and John, eds., Electoral Politics, 233-76. For Thailand, see Surin Maisrikrod, "Political Reform and the New Thai Electoral System" in John Fuh-sheng Hsieh and David Newman, eds., How Asia Votes (New York: Chatham House, 2002), 196. For the Philippines, see Gabriella R. Montinola, "Parties and Accountability in the Philippines," Journal of Democracy 10 (January 1999): 126-40.

5. See Benjamin Reilly, "Electoral Systems for Divided Societies," Journal of Democracy 13 (April 2002): 156-70.

6. See Matthew S. Shugart and Martin P. Wattenberg, eds., Mixed-Member Electoral Systems: The Best of Both Worlds? (New York: Oxford University Press, 2001); and Benjamin Reilly, "The Global Spread of Preferential Voting: Australian Institutional Imperialism?" Australian Journal of Political Science 39 (July 2004): 253-66.

7. Aurel Croissant, "Electoral Politics in South Korea," in Croissant, Bruns, and John, eds., Electoral Politics, 257.

8. Christof Hartmann, Graham Hassall, and Soliman M. Santos, Jr., "Philip- 
pines," in Nohlen, Grotz, and Hartmann, eds., Elections in Asia and the Pacific, 195.

9. Paige Johnson Tan, "Anti-Party Reaction in Indonesia: Causes and Implications," Contemporary Southeast Asia 24 (December 2002): 484-508.

10. Dwight Y. King, Half-Hearted Reform: Electoral Institutions and the Struggle for Democracy in Indonesia (London: Praeger, 2003), 51.

11. Dai-Kwon Choi, "The Choosing of Representatives in Korea," in Graham Hassall and Cheryl Saunders, eds., The People's Representatives: Electoral Systems in the Asia-Pacific Region (Sydney: Allen \& Unwin, 1997), 83.

12. Margarita Estévez-Abe, "Japan's Shift Toward a Westminster System: A Structural Analysis of the 2005 Lower House Election and Its Aftermath," Asian Survey 46 (August 2006): 632-51.

13. See Hyug Baeg Im, "Faltering Democratic Consolidation in South Korea: Democracy at the end of the 'Three Kims' Era," Democratization 11 (December 2004): 179-98.

14. See Allen Hicken, "From Province to Parliament: Party Aggregation in Developing Democracies," paper presented at the annual meeting of the American Political Science Association, Philadelphia, Pennsylvania, September 2003.

15. For an example, see Aart C. Kraay, Daniel Kaufmann, and Massimo Mastruzzi, "Governance Matters IV: Governance Indicators for 1996-2004," World Bank Policy Research Working Paper Series No. 3630, May 2005.

16. See Michael Taylor and V.M. Herman, "Party Systems and Government Stability," American Political Science Review 65 (March 1971): 28-37.

17. As Markku Laakso and Rein Taagepera write, "the number of parties must be operationally defined in a way that takes into account their relative size. . . . Rather than take the number of all existing parties, including even the very smallest, one visibly has a need for a number that takes into account their relative size. We will call this number the 'effective number of parties'... The effective number of parties is the number of hypothetical equal-size parties that would have the same total effect on fractionalization of the system as have the actual parties of unequal size." See Laakso and Taagepera, "'Effective' Number of Parties: A Measure with Application to West Europe," Comparative Political Studies 12 (April 1979): 3-4. For further information on the definition and calculation of the effective number of parties, see Rein Taagepera and Matthew Soberg Shugart, Seats and Votes: The Effects and Determinants of Electoral Systems (New Haven: Yale University Press, 1989), 78-80.

18. See Benjamin Reilly, "Political Reform in Papua New Guinea: Testing the Evidence," Pacific Economic Bulletin 21:1 (2006): 187-94.

19. For more on these issues, see Benjamin Reilly, Democracy and Diversity: Political Engineering in the Asia-Pacific (Oxford: Oxford University Press, 2006). 